\title{
Amateur Sports of the Elderly: A Chance for Health and a Higher Quality of Life
}

\author{
Paweł F. Nowak \\ Department of Physical Education and Physiotherapy, Opole University of Technology, Opole, Poland \\ Email: pawel.fryderyk.nowak@gmail.com
}

Received 20 May 2014; revised 21 June 2014; accepted 4 July 2014

Copyright (C) 2014 by author and Scientific Research Publishing Inc.

This work is licensed under the Creative Commons Attribution International License (CC BY).

http://creativecommons.org/licenses/by/4.0/

(c) (i) Open Access

\section{Abstract}

A significant increase in sports-leisure activity events in recent years presents the opportunity to compete in all age categories. Among the many sport varieties, special attention ought to be paid to amateur sports-recreational sports, particularly in the context of the increasing leisure time among the elderly. Recreational sports activities are free of many distortions and defects of the modern professional sport. Recreational sports are egalitarian, not exclusive. The health paradigm is always at the heart of it, along with a strong emphasis on hedonism. Sport activities reveal self-fulfillment as the highest needs, giving fulfillment and satisfaction. The ease in the selection of a sports goal makes the amateur sports an important tool for the shaping of persons' life and health. A sports goal, which is participating in sports events, provides a strong motivation for systematic work. Striving for transgression is a source of strong emotions and satisfaction. Struggling with a persons' own body, with old age, may be a valuable challenge that would positively impact wellbeing in the psychosocial aspect. This study shows a social phenomenon of sports activity among the elderly, dynamically growing in Poland. It also presents multiple benefits for the general wellbeing as well as the potential threats which a lack of distance to the sports rivalry may cause when it crosses the line behind which a persistent pursuit of the purpose (sport result) may end up in health damage. The line between recreation and sport is thin and difficult to distinguish. Animators, trainers, and instructors need to skillfully manage the interests of older people so that their involvement in physical activity determines a safe and healthy lifestyle.

\section{Keywords}

Recreational Sports, Old Age, Health, Quality of Life

\section{Introduction}

The activation of individuals beyond retirement age is currently an increasingly important topic of social policy 
and various media, not only in Poland. A problem more and more frequently discussed is not so much the concern for the further extension of life, as the care for the successful aging, meaning a reinforcement of life activity, maintaining the mental acuity and physical fitness on a satisfactory level [1].

It is well known that due to the biological mechanisms of adaptation, activity is a determinant of fitness [2]. It not only stimulates the development of physical fitness, but also has a significant impact on human wellbeing as a whole (psychological, social and spiritual).

Older people who exercise regularly are more fit and less likely to fall ill standing out for their serenity and optimism [3]-[5]. A strong relationship exists between health and physical activity of the elderly [6] [7]. Scientists prove numerous health benefits of physical activity programmes dedicated to the elderly [8].

Studies confirm that the lack or insufficient level of physical activity accelerates the processes of senile involution [9]. However, the physical activity of the adult population is poor, inadequate, and decreases further with age [10]-[12]. Unsatisfactory attitude towards this activity in our country is a complex and preexisting problem, affecting all age groups.

The lifestyle of the elderly rarely includes physical activities, either for prophylaxis or hedonistic reasons—as a way of spending leisure time; this is especially in the countries of Central and Eastern Europe, including Poland, where physical activity is blocked due to cultural factors. This is mainly a problem in rural areas [13].

Polish pensioners spend their leisure time in the vast majority by helping their children, grandchildren out, working on the lot, and watching television; physical activity is usually limited to the necessary activities of daily living, such as cleaning and cooking. Lack of tradition (and also low awareness of the role of physical activity in a person's life in old age) inhibits the development of infrastructure, recreational products and services dedicated to elderly people for many years. It is constantly very hard to persuade to participate in physical activities, especially for the elderly. There are still many barriers: physical, socio-economic, infrastructural and organizational, and psychological as well [14] [15].

The reduction of senile disability, while contributing to the independence in old age, clearly affects the quality of life, as does satisfaction in participation in social and professional life or in favorite leisure activities (with an established goal). An example of such an activity, both for the individual or for the collective, may be found in physical recreation, specifically in health training, which can lead to the highest level of sophistication in this area of activity - recreational sports.

The aim of this study is to present a rapidly growing social phenomenon in Poland, which is the sports activity among the elderly.

\section{Comprehensive Activation of the Elderly}

The acceleration of the aging process and the reduction in the quality of life takes place in many cases in the moment of retirement. An excess of leisure time is becoming a problem at that time. It particularly affects individuals who have so far been professionally very active, for whom the retiree status and in this respect a progressing social alienation leads to a lower subjective well-being [16]. In highly developed societies the problem of leisure time is not so much the amount of time as the proper way of spending it. Therefore, any kind of educational impact, aiming to acquire the ability to use free time for the benefit of individual development is most desirable, and should be applied at any age.

In recent years, owing to the globalization processes and the democratic-liberal trends in the economic, social and moral spheres, hitherto little known ways of experiencing old age may be gradually observed in the countries of Central and Eastern Europe: the active aging and the leisure time aging models [17].

The active aging model is an attempt to continue to work during retirement (often in a modified form, to a limited extent), or engaging in work for the society. Treating retirement as leisure and entertainment presents, on the other hand, the leisure time aging model. Both models are interrelated and focused on individual development in the context of the affirmation of the quality of life.

Thus, consumption patterns adopted by developing societies also apply to the area of coping with old age. Spending the time to support the family, aimed to prevent social uselessness, is highly culturally conditioned and often limits leisure used for self-development. At the same time, differentiation of life strategies for leisure in retirement in Poland is becoming more and more evident. Various breaking of normative behaviour is in progress, behaviour usually assigned to the status of being a pensioner. Much depends on the economic status, current lifestyle, professional work, education, awareness, needs and habits formed. The leisure time aging 
model is usually present when the family ties are strong and resemble rather relationships than bonds. Strong commitment in sport may be a compensation for a lack of family, the result of a more or less conscious fear of loneliness and senile disability.

Nowadays, the family ceases to be the only place to engage needs associated with life activity of the elderly. More and more symptoms of activation of the elderly are to be found, including universities of the third age (now 477 in Poland, with approx more than 100 thousand students), various associations and foundations, whose chief aim is to improve the quality of life in old age [18].

The recreational services market, aimed at people of all ages, is dynamically developing, and even amateur sports of the elderly is gaining popularity. Although more and more institutions in Poland shows activity in the psychophysical rehabilitation of older people (including universities of the third age, activities organized by The Society for the Promotion of Sport and Physical Activity TKKF, municipal and district centers and sports facilities, community centers and social welfare centers), still only few of the elderly participate in their programmes. R. Rowiński [19] draws attention to the need for a full geriatric care system, coordinated by local authorities, in which physical activities should play an important role.

Activities undertaken in group create bonds and protect against loneliness, reduce sense of loneliness [20]. Amateur sports clubs provide social support to the elderly, but also a chance for an intergeneration dialogue. It is because in the sports world everyone is equal, and, for example, all address each other by name regardless of age [21].

It is commonly believed that a life of a comprehensive activity is a successful life. Active people participating in organized activities during leisure time tend to have a creative attitude towards their own life. Achieving satisfaction from life itself demands appropriate strategies to be used. Those strategies must not mean avoiding obstacles - on the contrary. Activity (as in the ability to make the effort) is a value in itself. The very being active, not necessarily being highly fit, can be a source of wellbeing [22]. Naturally, a necessary level of fitness is needed in order to be active. Thus, physical activity and fitness can be specified as the important determinants of the quality of life of the elderly.

The problems of physical activity of older people are usually considered in terms of biopsychosocial health. Health training, which aims to develop physical and health-oriented fitness as a deliberate, systematic, programmable process, is an effective instrument to improve the physical wellbeing [23] [24]. Several scientific studies show lot of benefits for the elderly of practicing recreational sport. The appropriate exercises (selection and frequency) reduce the risk of premature death, prevent the formation and growing of certain cancers, and reduce the risk of osteoporosis, many diseases of cardiovascular and other diseases of civilization. Physical activity helps to solve the most important, the most common health problems of the elderly, giving the chance to extend healthy life [25]-[27]. It is the work on psychosocial wellbeing that creates greater difficulties, although research shows that the active participation of older people in organized activities within Peer group positively influences the sense of life satisfaction [28].

Sports activities, with a competitive element and preferably in teamwork, may be a desirable alternative.

\section{The Essence of Recreational Sports}

In the course of socio-economic and cultural civilization transformations, the number of the elderly practicing sports at a high level has increased [29].

Of the many varieties of sports, special attention should be paid to amateur and recreational sport, especially in the context of the increasing leisure time among the elderly.

Recreational sports is an activity with rules, aimed at improving physical fitness necessary for every day functioning. This activity takes on the form of a struggle of a person with oneself or with others, and may also contain an element of fun and play. The origins of the idea of recreational sports can be traced to a concept of "sport for all”, popular around the world, which was established in 1966 as an integral part of recreational and leisure issues raised [30]. By definition, the concept assumes rivalry of a playful nature, without any negative consequences so obviously associated with professional sports. The main goal is to preserve and even develop the health potential instead of endlessly maximize fitness. The development of physical fitness is needed in order to practice sports rivalry. It's a safe imitation of the real world of sports. It is therefore a specific type of play, being part of leisure time.

Recreational sports activities are free of many distortions and defects of the modern professional sport. Recr- 
eational sports are egalitarian, not exclusive. The health paradigm is always at the heart of it, along with a strong emphasis on hedonism. Sport activities reveal self-fulfillment as the highest of needs, giving fulfillment and satisfaction.

Modern sport is a business, a media industry, and is becoming more and more open to people with disabilities and the elderly people, because these groups — in spite of the relatively low level of sport_can create a media spectacle. The elderly participate in most of the recreational sports usually available to individuals most predisposed in age to participate in them.

From a social point of view, it is particularly worth to promote those activities which allow maximizing health benefits. Those are mainly health-oriented endurance sports disciplines which base on oxygen efficiency [31]. The most popular are long-distance running, cycling, long distances swimming, cross-country skiing and triathlon. Relatively high sports results may be achieved in the endurance disciplines even in old age, this being a significant motivating factor for practicing them [32].

Researchers prove that physical training may be safe and effective also in a significantly advanced age [33]. With increasing age, risk of injury declines in group of physically active people [34].

\section{Recreational Sports Events-Also for the Elderly}

Sports activity is not only systematic training, but also participation in sports. Healthy, active lifestyle is being promoted by mass sports events, which in Poland become more and more numerous along with the increasing number of participants of all ages.

The most notable example of promoting activity among the elderly are sports events in which a team classification is carried out. For example, for a team of four to take part in the competition and be classified it must have at least one person over 50 years of age and one under 25 years of age. There may be many more similar examples of activating a relationship between generations. The recreation development trend should follow exactly in the direction of multi-generational family recreation.

Many recreational activity centers, fitness clubs, institutions involved the organization of leisure time for the elderly offer sports activities, participation in recreational events, where rivalry takes place. The aim is not so much a rivalry with opponents (as in other people), as a struggle with the person self, with the distance, the route, the weather, external constraints that are inherent in the environment, and internal constraints, which every person has. Striving for transgression is a source of strong emotions and satisfaction. Struggling with a persons' own body, with old age, may be a valuable challenge that would positively impact wellbeing in the psychosocial aspect, including a positive self-image and an increase of self-esteem of the individual in society [35].

Old age is a continuation of the earlier stages of life. In elderly sports, people involved are usually former participants, those who cannot and will not part with a sport lifestyle. Those who constantly set new goals are driven by a strong need for self-development.

Gerontologists stress that the quality of life of the elderly largely reflects the lifestyle in youth, especially in adulthood [36].

An inactive lifestyle, lacking in exciting experience, often causes depression and frustration. Lack of purpose in life has a negative effect on the quality of life (mental state) in the elderly. Participation in a sport and recreation event may become an engaging goal, which is admirable in society, and gives the participant a meaning of life [37].

The ease in setting a goal makes recreational sports an important tool for shaping life and health. The goal may be to improve a sports result for a person, overcome weakness, and overcome the individual self. Striving for perfection may become an attractive philosophy of life [38]. Participation in sport and recreation events facilitates the establishing of relationships [39].

In Poland, a dynamic growth of the number of open sports and recreation events is observed, especially running events. There are also sports events promoting cross-country skiing, Nordic walking, cycling, swimming, triathlon. These types of events are not closed for the elderly, on the contrary, they promote their activities, and their organizers devote special souvenirs from events such as for the oldest participant. The elderly are being motivated by awards for covering a distance (e.g., a commemorative medal, diploma, certificate), awards (trophies and financial awards) for taking first three places in age category, and are often exempt from the entry fee. The prerequisites for attending such events are: minimum age of 18 (due to the nature of the exercises), paying the contribution fee and signing a document on participating on the person's own risk. Some events are of a 
touring character: rallies or kayaking events. Their diversity is owing chiefly to all organizers of commercial ventures. Many events are health-oriented, with health programmes included, e.g., free medical tests onsite.

\section{Running as the Most Popular Form of Recreation and Sports}

It may be noted that in the last few years running has been gaining in fashion in Poland; there are many associations of running aficionados and three nationwide hobby magazines for them. Equally high dynamics of this phenomenon in such a short time are not recorded in the neighbouring countries. For example in 2009 in the Czech Republic, a country with a long tradition of running and recreation developed among people of all ages, 859 open running events were held, while in Poland-1297 (for comparison—in 2000 nearly six times less of them were held, only 207).

Running as a mass form of recreation (jogging) turned into a sports competition in all age categories. Those with 70 years or more behave and feel like real athletes, and most of all feel younger-especially if they win with younger people.

Marathons (over a distance of $42.2 \mathrm{~km}$ ) enjoy enduring popularity around the world since the 1970's. In Poland, the most numerous marathons gather few thousand people, in Western Europe and the United States the number increases to tens of thousands, with $50 \%$ of participants over the age 40 years.

Modern recreational sport, with its mass, egalitarian character, with its lack of selection and voluntariness, is certainly a phenomenon of social and economic nature. It is a sports activity, by definition health-oriented and oriented on moral and ethical values, often showing full tolerance in a crowd of several thousand.

Undoubtedly, the high fitness of individuals over 60 years of age is due to years of training in youth. Personal experiences of practice of sport in period of school education result in involvement in sport at later periods of life [40] [41]. E. Kozdroń and P. Szczypiorski [42] declare that the hardest thing is to encourage physical activity in the elderly that were inactive earlier in life; but when physical activity becomes their way of life, they rarely give up on it. All the more so as it is a drawing activity, and, as elder runners report, an activity they are likely to become addicted to; what is also confirmed by scientists [43] [44].

\section{Is Participating in Recreational Sports Good for Health?}

Lack of distance to sporting activities may result in negative consequences. Novice runners often forget that they are amateurs, and fail to set their training objectives accordingly. It results in sports results overriding health values. This distressing effect is often build up by event organizers, and powers up rivalry among this group of people. Establishing of valuable prizes in age categories (e.g., 70-year-olds, 80-year-olds) becomes a not necessarily invited practice.

Polish Veterans Championships, an event for the elderly of 60 - 70 years of age and similar, are popular and organized in different disciplines. Concerns of ethical and moral nature are raised however for extreme events, not necessarily having much to do with health—such as a race for 100 -year-olds.

It happens that elderly participants beat the 20-year-olds, certainly gaining respect among potential supporters and event participants themselves. And this certainly additionally encourages training and improving results.

It may be argued how far the phenomenon of elderly amateur sports is good for a person's health. The socalled extreme sports certainly cannot be identified with health. A. Pawłucki [45] is very critical about extreme sports, even emphasizing the social harm.

The element of rivalry in recreational sports may pose a threat to the health of an amateur [46]. Yet it is the rivalry, and the way to deal with it, which is crucial. From the health point of view, it seems reasonable to recommend only playful rivalry, without the consequences of failure.

Many elderly have strong creative aspirations in relation to themselves and their surroundings, resulting in excessive ambition in achieving sports results, often close to exaggeration. It promotes the development of stress situation by creating an atmosphere of struggle, not fun. Rivalry is even introduced during activities in recreational Nordic Walking clubs. Events are organized, which are not only meetings to promote sports activity but are also competitions with rivalry for awards in various categories, age being the most common.

An example of unjustified rivalry in a typical recreational and health-oriented movement is the Polish Championship in Nordic Walking [47].

The line between recreation and sport is thin and difficult to distinguish; regarding a hobby of a person as being fun-with an appropriate distance, or engaging in a hobby too seriously, submitting to sports completely. 
Sport then becomes work, not fun. Animators, trainers, instructors need to skillfully manage the interests of older people so that their involvement in physical activity determines a safe and healthy lifestyle [48].

\section{Conclusions}

Active participation of the elderly in physical culture certainly will change due to ongoing commercialization of the life and culture. Owing to this commercialization, there is both a chance not only to promote health and spread health culture, but also to develop healthy attitudes towards physical activity, sports activities in particular.

Elderly sports are a chance to extend life in full fitness and hence-a chance for a higher quality of life. For this to happen, health training should be popularized, especially in the media, and not, for the most part, professional sports and cheering as is currently the case.

Health training, aimed at the development of physical fitness and health in order to participate in sports and recreational events, is a good strategy for leisure time. Sports lifestyle entails (forces, even) a number of positive changes in health behavior, creating a healthy lifestyle. Adherence to the principles of a healthy lifestyle is a prerequisite for the success of sports (the objectives), so often people forgo addictions and bad habits because of training.

A sports goal, which is participating in sports events, provides a strong motivation for systematic work. Collecting symbols of success, e.g., medals of completing a cross-country skiing run and cross-country street run also encourages systematic work (training).

The phenomena described above are certainly worth observing, and the processes in the recreation of the elderly are worth examining. Old age is a challenge not only for aging people, but also for the institutions dealing with the elderly. It's also a chance to develop new services and sports and recreation products.

The organizers of leisure for the elderly should create an atmosphere for a healthy lifestyle and not a sport competition. They should teach how to play with sports and sport rivalry, teach distance to a sports hobby and teach how to not exceed the limit at which the persistent pursuit of the goal (sports result) may end up in health damage.

\section{References}

[1] Bath, P.A. and Morgan, K. (1998) Customary Physical Activity and Physical Health Outcomes in Later Life. Age and Ageing, 27, 29-34. http://dx.doi.org/10.1093/ageing/27.suppl_3.29

[2] Spirduso, W.W. and Cronin, D.L. (2001) Exercise Dose-Response Effects on Quality of Life and Independent Living in Older Adults. Medicine \& Science in Sports \& Exercise, 33, 98-608. http://dx.doi.org/10.1097/00005768-200106001-00028

[3] Blomstrand, A., Björkelund, C., Ariai, N., Lissner, L. and Bengtsson, C. (2009) Effects of Leisure-Time Physical Activity on Well-Being among Women: A 32-Year Perspective. Scandinavian Journal of Public Health, 37, 706-712. http://dx.doi.org/10.1177/1403494809341092

[4] Koivula, N. (1999) Sport Participation: Differences in Motivation and Actual Participation Due to Gender Typing. Journal of Sport Behavior, 22, 360-381.

[5] Ruuskanen, J.M. and Ruoppila, I. (1995) Physical Activity and Psychological Well-Being among People Aged 65 to 84 Years. Age and Ageing, 24, 292-296. http://dx.doi.org/10.1093/ageing/24.4.292

[6] Buchner, D.M., Beresford, S.A., Larson, E.B., LaCroix, A.Z. and Wagner, E.H. (1992) Effects of Physical Activity on Health Status in Older Adults. Intervention Studies. Annual Review of Public Health, 13, 469-488. http://dx.doi.org/10.1146/annurev.pu.13.050192.002345

[7] Fentem, P.H., Turnbull, N.B. and Bassey, E.J. (1990) Benefits of Exercise: The Evidence. University of Manchester Press, Manchester.

[8] Perrig-Chiello, P., Perrig, W.J., Ehrsam, R., Staehelin, H.B. and Krings, F. (1998) The Effects of Resistance Training on Well-Being and Memory in Elderly Volunteers. Age and Ageing, 27, 469-475. http://dx.doi.org/10.1093/ageing/27.4.469

[9] Gregg, E.W., Cauley, J.A., Stone, K., Thompson, T.J., Bauer, D.C., Cummings, S.R. and Ensrud, K.E. (2003) Relationship of Changes in Physical Activity and Mortality among Older Women. The Journal of the American Medical Association, 289, 2379-2386. http://dx.doi.org/10.1001/jama.289.18.2379

[10] Buchman, A.S., Wilson, R.S., Yu, L., James, B.D., Boyle, P.A. and Bennett, D.A. (2014) Total Daily Activity Declines 
More Rapidly with Increasing Age in Older Adults. Archives of Gerontology and Geriatrics, 58, 74-79. http://dx.doi.org/10.1016/j.archger.2013.08.001

[11] Drygas, W., Bielicki, W. and Pekka, P. (2002) Evaluation of Inhabitants’ Activity of Six European Countries. Project Bridging East—West Health Gap. Medycyna Sportowa, 18, 169-174.

[12] Drygas, W., Kwaśniewska, M., Szcześniewska, D., Kozakiewicz, K., Głuszek, J., Wiercińska, E., Wyrzykowski, B. and Kurjata, P. (2005) Evaluation of the Level of Physical Activity of the Adult Population in Poland. The Results of the WOBASZ Program. Kardiologia Polska, 63, S636-S640.

[13] Chinn, D.J., White, M., Harland, J., Drinkwater, C. and Raybould S. (1999) Barriers to Physical Activity and Socioeconomic Position: Implications for Health Promotion. The Journal of Epidemiology and Community Health, 53, 191-192. http://dx.doi.org/10.1136/jech.53.3.191

[14] Crombie, I.K., Irvine, L., Williams, B., McGinnis, A.R., Slane, P.W., Alder, E.M. and McMurdo, M.E.T. (2004) Why Older People Do Not Participate in Leisure Time Physical Activity: A Survey of Activity Levels, Beliefs and Deterrents. Age and Ageing, 33, 287-292. http://dx.doi.org/10.1093/ageing/afh089

[15] Grant, B.C. (2001) You're Never Too Old: Beliefs about Physical Activity and Playing Sport in Later Life. Ageing and Society, 21, 777-798. http://dx.doi.org/10.1017/S0144686X01008492

[16] Waddell, G. and Burton, A.K. (2006) Is Work Good for Your Health and Well-Being? TSO, London.

[17] Sobiesiak, P. and Zalewska, J. (2011) Between Shame and Sociability. Models of Social Participation of Older People. In: Racław, M., Ed., Public Concern, Private Care, the Local Communities for the Elderly, Instytut Spraw Publicznych, Warszawa, 257-273.

[18] Januszczyk-Krysińska, J. (2006) Universities of the Third Age as the Opportunity to Improve the Quality of Life of Seniors. Polish Journal of Public Health, 116, 343-345.

[19] Rowiński, R. (2007) Recreational and Tourism Activity as a Way of Improving Older People. In: Dziubiński, Z., Ed., Roads and Wilderness of Sports and Tourism, AWF, Warszawa, 421-426.

[20] McAuley, E., Blissmer, B., Marquez, D.X., Jerome, G.J., Kramer, A.F. and Katula, J. (2000) Social Relations, Physical Activity, and Well-Being in Older Adults. Preventive Medicine, 31, 608-617. http://dx.doi.org/10.1006/pmed.2000.0740

[21] Schulenkorf, N. (2012) Sustainable Community Development through Sport and Events: A Conceptual Framework for Sport-for-Development Projects. Sport Management Review, 15, 1-12. http://dx.doi.org/10.1016/j.smr.2011.06.001

[22] Oerlemans, W.G.M., Bakker, A.B. and Veenhoven, R. (2011) Finding the Key to Happy Aging: A Day Reconstruction Study of Happiness. Journal of Gerontology: Psychological Sciences, 66, 1-10.

[23] Corbin, C.B., Welk, G.J., Corbin, W.R., Welk, K.A. (2006) Fundamental Concepts of Fitness and Wellness with Nutrition Update. McGraw-Hill, New York.

[24] Nelson, M.E., Rejeski, W.J., Blair, S.N., Duncan, P.W., Judge, J.O., King, A.C., Macera, C.A. and Castaneda-Sceppa, C. (2007) Physical Activity and Public Health in Older Adults: Recommendation from the American College of Sports Medicine and the American Heart Association. Medicine \& Science in Sports \& Exercise, 39, 1435-1445. http://dx.doi.org/10.1249/mss.0b013e3180616aa2

[25] Gremeaux, V., Gayda, M., Lepers, R., Sosner, P., Juneau, M. and Nigam, A. (2012) Exercise and Longevity. Maturitas, 73, 312-317. http://dx.doi.org/10.1016/j.maturitas.2012.09.012

[26] Ornelas, M., Benavides, V., Aguirre, J.F., Gastélum, G. and Rodríguez-Villalobos, J.M. (2014) Physical Activation of Elderly and the Decrease of Falling Risk. Health, 6, 1116-1123. http://dx.doi.org/10.4236/health.2014.611138

[27] Taylor, D. (2014) Physical Activity Is Medicine for Older Adults. Postgraduate Medical Journal, 90, 26-32. http://dx.doi.org/10.1136/postgradmedj-2012-131366

[28] Stubbe, J.H., de Moor, M.H.M., Boomsma, D.I. and de Geus, E.J.C. (2007) The Association between Exercise Participation and Well-Being: A Co-Twin Study. Preventive Medicine, 44, 148-152. http://dx.doi.org/10.1016/j.ypmed.2006.09.002

[29] Dionigi, R. (2006) Competitive Sport and Aging: The Need for Qualitative Sociological Research. Journal of Aging \& Physical Activity, 14, 365-379.

[30] Kocemba, W. (1997) Health Promotion and Physical Fitness and Sport for All in USA. Promocja Zdrowia. Nauki Spotecznei Medycyna, 12-13, 113-115.

[31] Blair, S.N., LaMonte, M.J. and Nichaman, M.Z. (2004) The Evolution of Physical Activity Recommendations: How Much Is Enough? The American Journal of Clinical Nutrition, 79, 913-920.

[32] Foster, C., Wright, G., Battista, R.A. and Porcari, J.P. (2007) Training in the Aging Athlete. Current Sports Medicine Reports, 6, 200-206. 
[33] Xu, D.Q., Li, J.X. and Hong, Y. (2006) Effects of Long Term Tai Chi Practice and Jogging Exercise on Muscle Strength and Endurance in Older People. British Journal of Sports Medicine, 40, 50-54. http://dx.doi.org/10.1136/bjsm.2005.019273

[34] Schneider, S., Seither, B., Tönges, S. and Schmitt, H. (2006) Sports Injuries: Population Based Representative Data on Incidence, Diagnosis, Sequelae, and High Risk Groups. British Journal of Sports Medicine, 40, 334-339. http://dx.doi.org/10.1136/bjsm.2005.022889

[35] Eman, J. (2012) The Role of Sports in Making Sense of the Process of Growing Old. Journal of Aging Studies, 26, 467-475. http://dx.doi.org/10.1016/j.jaging.2012.06.006

[36] Zielińska-Więczkowska, H., Kędziora-Kornatowska, K. and Kornatowski, T. (2008) Old Age as a Challenge. Gerontologia Polska, 16, 131-136.

[37] Paluska, S.A. and Schwenk, T.L. (2000) Physical Activity and Mental Health. Sports Medicine, 29, 167-180. http://dx.doi.org/10.2165/00007256-200029030-00003

[38] Kerr, J.H. (1997) Motivation and Emotion in Sport. Reversal Theory. Psychology Press Taylor \& Francis Group, Hove.

[39] Misener, L. and Mason, D.S. (2006) Creating Community Networks: Can Sporting Events Offer Meaningful Sources of Social Capital? Managing Leisure, 11, 39-56. http://dx.doi.org/10.1080/13606710500445676

[40] Curtis, J., McTeer, W. and White, P. (1999) Exploring Effects of School Sport Experiences on Sport Participation in Later Life. Sociology of Sport Journal, 16, 348-365.

[41] Vanreusel, B., Renson, R., Beunen, G., Claessens, A.L., Lefevre, J., Lysens, R., Eynde, B.V. and Leuven, K.U. (1977) A Longitudinal Study of Youth Sport Participation and Adherence to Sport in Adulthood. International Review for the Sociology of Sport, 32, 373-387. http://dx.doi.org/10.1177/101269097032004003

[42] Kozdroń, E. and Szczypiorski, P. (2001) Physical Activity of Older People. Program Proposals. In: Charzewski, J., Ed., Problems of Aging, AWF, Warszawa, 105-110.

[43] Hall, H.K., Hill, A.P., Appleton, P.R. and Kozub, S.A. (2009) The Mediating Influence of Unconditional Self-Acceptance and Labile Self-Esteem on the Relationship between Multidimensional Perfectionism and Exercise Dependence. Psychology of Sport and Exercise, 10, 35-44. http://dx.doi.org/10.1016/j.psychsport.2008.05.003

[44] Roper, E.A., Molnar, D.J. and Wrisberg, C.A. (2003) No “Old Fool”: 88 Years Old and Still Running. Journal of Aging \& Physical Activity, 11, 370-388.

[45] Pawłucki, A. (2005) Person in the Pedagogy of the Body. Wydawnictwo Olsztyńskiej Szkoły Wyższejim. Józefa Rusickiego, Olsztyn.

[46] Kallinen, M. and Markku, A. (1995) Aging, Physical Activity and Sports Injuries. An Overview of Common Sports Injuries in the Elderly. Sports Medicine, 20, 41-52. http://dx.doi.org/10.2165/00007256-199520010-00004

[47] Nowak, P.F. (2011) Nordic Walking Comptetions via Healthy Aspect of Mass Recreation. Zeszyty Naukowe WSTiJ. Turystykai Rekreacja, 8, 129-143.

[48] Nowak, P.F. (2010) Recreational Sport-On the Border of Pro-Health Values. Zdrowie, Kultura Zdrowotna, Edukacja, 6, 129-134. 
Scientific Research Publishing (SCIRP) is one of the largest Open Access journal publishers. It is currently publishing more than 200 open access, online, peer-reviewed journals covering a wide range of academic disciplines. SCIRP serves the worldwide academic communities and contributes to the progress and application of science with its publication.

Other selected journals from SCIRP are listed as below. Submit your manuscript to us via either submit@scirp.org or Online Submission Portal.
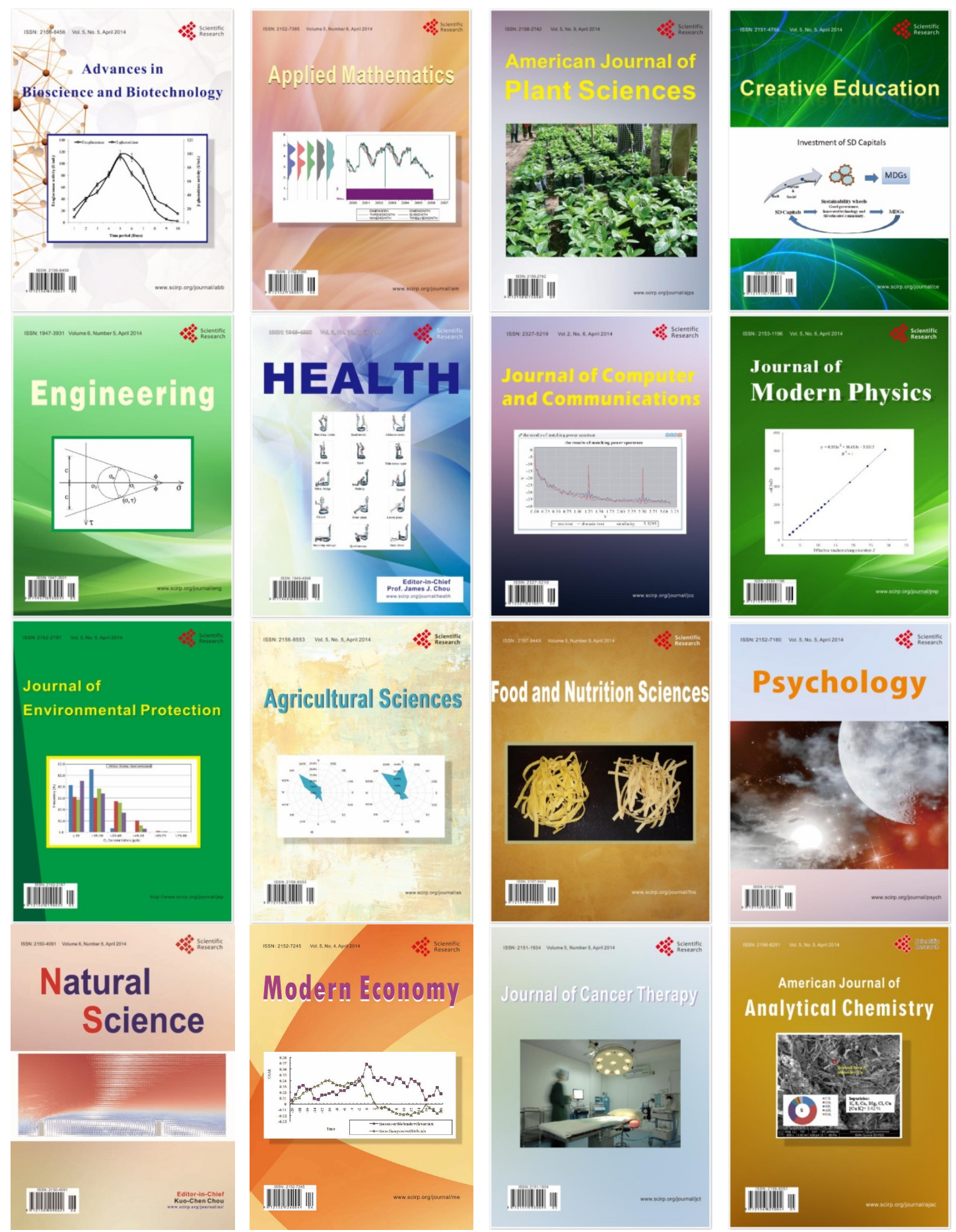